\title{
Akibat Hukum Hibah Wasiat yang Melebihi Legitime Portie
}

\author{
Yanuar Suryadini dan Alifiana Tanasya Widiyanti \\ Yanuar.Suryadini-2018@fh.unair.ac.id \\ Universitas Airlangga
}

\begin{abstract}
Keywords: $\quad$ Abstract
Testamentary The western legal system sourced from Burgerlijk Weatboek regulates the testamentary will Gifting; Legitime contained in article 957 BW explains that the testamentary will is a special stipulation, which Portie; Cancellation bequeaths to others giving an object such as movable or immovable property, or giving us the Testamentary usufructuary rights in whole or some of the legacy. The determination of a will is a will of Gifting. the heir. In article $1683 \mathrm{BW}$ jo article $1682 \mathrm{BW}$ explains that a grant is said to be valid if it applies to all parties if the recipient of the grant has received an object given from the donor with valid evidence. This research was conducted using the normative juridical method which is a method that refers to the provisions of the applicable legal rules, the legal rules also on the rules in Burgerlijk Weatboek relating to grants. granting property is indeed not prohibited in the law but there are rules and calculations in the testamentary will to the person who receives the grant so as not to harm the heirs because in Burgerlijk Weatboek there is an absolute right (legitime portie) to the heirs regulated in article $913 \mathrm{BW}$, if the heir is harmed, the heir can sue his portion to the court on the basis of article 913 BW regarding its absolute part (legitime portie) the right has been protected by law, even though there is a will that the inheritance's entire assets are given to the recipient of the grant. the legal consequences of the gifting that has been done if it harms the heirs in a decision that has legal force will still apply retroactively to the disputed object, the will given will no longer be the property of the recipient of the grant but will be as before and it is considered that the agreement never existed.
\end{abstract}

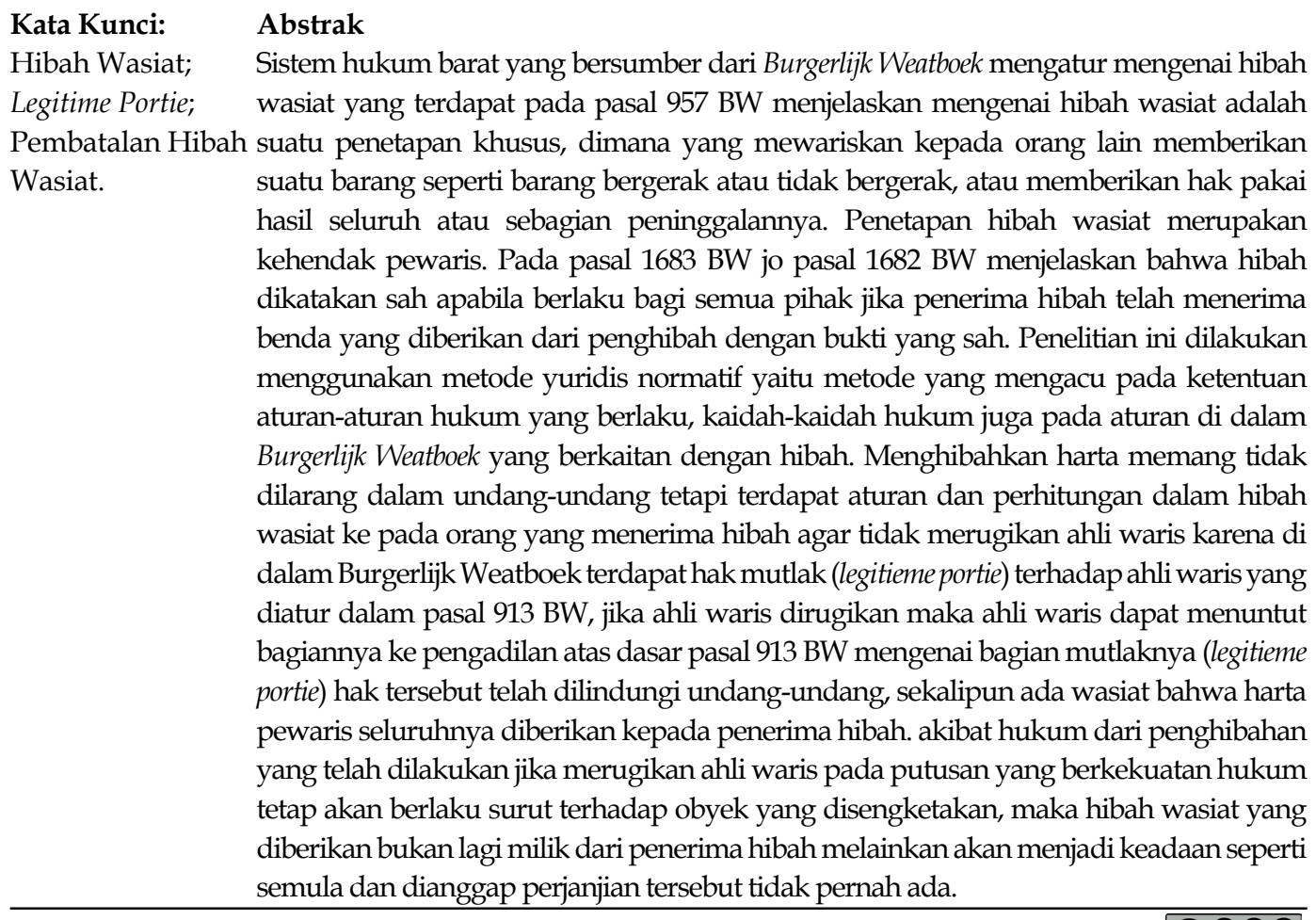




\section{Pendahuluan}

Indonesia adalah negara hukum, hal ini sesuai dengan ketentuan yang termuat pada Pasal 1 ayat (3) Undang-Undang Dasar 1945. Dengan ketentuan ini ditegaskan segala macam aspek dan aktivitas dalam masyarakat, pemerintahan, dan negara harus berlandaskan hukum. Namun dikarenakan belum adanya kodifikasi mengenai hukum waris pasca kemerdekaan, maka dasar hukum mengenai penyelesaian sengketa pewarisan masih menggunakan pasal 131 jo. 163 I.S. Jadi di Indonesia ragam sistem hukum waris yang berlaku bagi warga negara Indonesia, yaitu: ${ }^{1}$

1. Sistem hukum waris Barat dimana tertuang dalam Burgerlijk Wetboek yang berdasarkan ketentuan Pasal 131 I.S. jo. Staatsblad 1917 Nomor 12 jo. Staatsblad 1924 Nomor 557 jo. Staatsblad 1917 Nomor 12 tentang penundukan diri terhadap Hukum Eropa, maka Burgerlijk Wetboek tersebut berlaku bagi:
a. Orang-orang Eropa dan mereka yang dipersamakan dengan Eropa.
b. Orang Timur Asing Tionghoa.
c. Orang Timur Asing lainnya dan orang-orang Indonesia yang menundukkan diri kepada Hukum Eropa.

2. Sistem hukum waris Adat dimana pada saat terbentuk dipengaruhi oleh etnis di berbagai daerah lingkungan Hukum Adat, yang diberlakukan kepada golongan Bumi Putera. Yang tunduk pada hukum adat baik Matrilineal, Patrilineal, maupun Bilateral

3. Sistem hukum waris Islam, yang juga terdiri dari puralisme ajaran, seperti ajaran Kewarisan Ahlus Sunnah wal Jama'ah, ajaran Syi'ah. Yang paling dominan dianut di Indonesia adalah Ahlus Sunnah wal Jama'ah.

Hukum Waris Perdata Eropa awalnya hanya berlaku bagi Golongan Eropa, Dalam perjalanannya, Burgelijk Wetboek diberlakukan bagi golongan Timur Asing dan diberikan kemungkinan bagi Golongan Bumiputra untuk melakukan penundukan diri secara sukarela (gelijkstelling) terhadap Burgelijk Wetboek, di

\footnotetext{
1 M Idris Ramulyo, Perbandingan Hukum Kewarisan Islam Dengan Kewarisan Menurut Burgerlijk Wetboek (BW) (Sinar Grafika 2000).
} 
dalamnya termasuk hukum kewarisannya. Berdasarkan asas konkordansi, Hukum Perdata Belanda diberlakukan di Indonesia dan kodifikasi diumumkan pada tahun 1847 dengan Staatsblaad No.23. Dalam Burgerlijk Wetboek, tidak ada pasal yang menjelaskan pengertian hukum waris. Tetapi seperti pengertian yang telah diuraikan sebelumnya oleh penjelasan Subekti yang meskipun tidak menyebutkan definisi hukum kewarisan, dalam hukum waris Burgerlijk Wetboek berlaku satu asas, bahwa hanyalah hak dan kewajiban dalam lapangan hukum kekayaan harta benda saja yang dapat diwariskan.

Jadi, pada dasarnya pengertian kewarisan menurut BW memperlihatkan unsur berikut:

1. Seorang peninggal warisan (erf later) pada wafatnya meninggalkan kekayaan. Unsur pertama ini menimbulkan persoalan, yaitu bagaimana dan sampai di mana hubungan seorang peninggal warisan dengan kekayaannya yang dipengaruhi oleh sifat lingkungan kekeluargaan di mana si peninggal warisan berada;

2. Seseorang atau beberapa ahli waris (erf genaam) yang berhak menerima kekayaan yang ditinggalkan itu. Hal ini menimbulkan persoalan bagaimana dan sampai di mana harus ada tali kekeluargaan antara peninggal warisan dan ahli waris agar kekayaan si peninggal warisan beralih kepada si ahli waris;

3. Harta warisan (nalaten schap), yaitu wujud kekayaan yang ditinggakan dan beralih kepada ahli waris itu. Hal ini menimbulkan persoalan, yaitu bagaimana dan sampai di mana wujud kekayaan yang beralih itu dipengaruhi oleh sifat lingkungan kekeluargaan.

dimana si peninggal warisan dan ahli waris bersama-sama berada. Jadi hukum waris diciptakan untuk mengatur tata cara pembagian harta peningalan agar harta tersebut kedepannya dapat bermanfaat bagi waris atau ahli waris maupun pihak yang ditinggalkan secara adil dan baik. ${ }^{2}$

Sebagaimana dijelaskan pada Pasal 830 BW, pewarisan baru akan terjadi

2 Wirjono Prodjodikoro, Hukum Warisan Di Indonesia (Is Gravennage Vorkink Van Hove) (1962).[8]. 
bilamana terjadi suatu peristiwa hukum kematian. Dapat dilihat pada ketentuan Pasal 832 BW yang berhak mendapatkan harta warisan adalah keluarga sedarah, baik sah maupun luar kawin dan si yang hidup terlama. Jadi pada dasarnya ahli waris menurut hukum adalah pemilik atas semua barang, piutang dan hak dari pewaris hal ini terdapat pada Pasal 833 BW, akan tetapi Burgerlijk Wetboek memberikan hak pada pewaris dimana pewaris mempunyai hak untuk berkehendak setelah ia meninggal yang disebut dengan wasiat. Seperti yang termuat dalam Pasal 875 BW "Adapun yang dinamakan surat wasiat atau testamen ialah suatu akta yang memuat pernyataan seorang tentang apa yang dikehendakinya akan terjadi setelah ia meninggal dunia dan yang olehnya dapat dicabut kembali lagi". Jadi pemberian wasiat diberikan pada saat pemberi wasiat masih hidup, tetapi pelaksanaannya dilakukan pada saat pemberi wasiat meninggal dunia. Pasal 874 BW menyatakan bahwa segala harta peninggalan seseorang yang meninggal dunia, adalah kepunyaan para ahli warisnya menurut undang-undang, sejauh mengenai hal itu dia belum mengadakan ketetapan yang sah. Ketetapan yang sah tersebut ialah surat wasiat. Artinya, jika ada surat wasiat yang sah, surat wasiat harus dijalankan oleh para ahli waris. Sebaliknya, apabila tidak ada surat wasiat, semua harta peninggalan pewaris adalah milik ahli waris.

Ada dua jenis wasiat, yaitu wasiat pengangkatan waris (erfstelling) dan hibah wasiat (legaat).

1. Wasiat Pengangkatan Waris (erfstelling)

Pemberi wasiat memberikan harta kekayaannya dalam bentuk bagian baik itu seluruhnya, setengah, maupun sepertiga. Pemberi wasiat tidak menyebutkan secara spesifik benda atau barang apa yang diberikannya kepada penerima wasiat sesuai dengan Pasal 954 BW

2. Hibah Wasiat (legaat)

Pemberi wasiat memberikan beberapa barang-barangnya secara spesifik dari suatu jenis tertentu kepada pihak tertentu. Hal ini termuat dalam Pasal 957 BW.

Di dalam Pasal 832 Burgerlijk Wetboek menyebutkan bahwa yang berhak menjadi ahli waris ialah keluarga sedarah, baik yang sah menurut undang-undang 
maupun yang diluar perkawinan dan suami atau istri yang hidup terlama. Ahli hukum perdata membagi ahli waris menjadi beberapa golongan diantaranya:

1. Ahli waris golongan pertama, yaitu meliputi keluarga sedarah dalam garis lurus ke bawah si pewaris. Apabila pewaris meninggalkan seorang suami/ istri, maka berdasarkan undang-undang, suami atau istri disamakan dengan seorang anak, seperti dikatakan dalam Pasal 852 Burgerlijk Wetboek:

“anak-anak atau sekalian keturunan mereka, baik dilahirkan dari lain lain perkawinan sekalipun, mewaris dari kedua orang tua, kakekatau nenek atau semua keluarga sedarah mereka selanjutnya dalam garis lurus keatas, dengan tiada perbedaan antara laki dan perempuan dan tiada perbedaan berdasarkan kelahiran lebih dahulu, mereka mewaris kepala demi kepala, jika dengan si meninggal mereka bertalian keluarga dalam derajat ke satu dan masingmasing mempunyai hak karena diri sendiri dan mereka mewaris pancang demi pancang".

2. Ahli waris golongan kedua, meliputi orang tua, saudara dan keturunan dari saudara. Untuk menentukan bagian warisan dari orang tua, maka warisan dibagi dua bagian yang sama menurut banyaknya orang, antara orang tua dan saudara laki-laki dan saudara perempuan. Akan tetapi, bagian warisan dari orang tua tidak pernah kurang dari seperempat. Hal ini seperti tercantum dalam Pasal 854-855 Burgerlijk Wetboek.

3. Ahli waris golongan ketiga yaitu kakek dan nenek serta leluhur dan selanjutnya. Apabila si pewaris tidak meninggalkan keturunan, orang tua, saudara dan keturunan dari saudara, maka harta peninggalannya sebelum dibagi dibelah terlebih dahulu (kloving).

4. Ahli waris golongan keempat adalah keluarga selanjutnya yang menyamping. Apabila tidak ada ahli waris dalam garis yang satunya, maka seluruh warisan jatuh kepada ahli waris dalam garis lainnya. Hal ini seperti tercantum dalam Pasal 861 ayat (2) Burgerlijk Wetboek.

Keempat golongan ahli waris ialah golongan ahli waris yang mewaris berdasarkan kedudukannya, sedangkan untuk ahli waris yang mewaris berdasarkan penggantian dibagi atas beberapa golongan. Berdasarkan penggantian (bij plaatsvervulling) atau sering disebut dengan ahli waris tidak langsung yaitu diantaranya :

1. Penggantian dalam garis lurus ke bawah yang sah, berlangsung terus dengan tiada akhirnya. Dalam segala hal, pergantian seperti di atas selamanya diperbolehkan, baik dalam hal bilamana beberapa anak si yang meninggal mewaris bersama-sama dengan keturunan seorang anak yang telah meninggal lebih dulu, maupun sekalian keturunan mereka mewaris bersama-sama, satu 
sama lain dalam pertalian keluarga yang berbeda-beda derajatnya, hal ini diatur dalam Pasal 842 Burgerlijk Wetboek;

2. Penggantian dalam garis ke samping tiap saudara kandung/tiriyang meninggal lebih dulu digantikan oleh sekalian anaknya sehingga mereka mewaris bersama-sama dengan paman atau bibi mereka, hal ini diatur dalam Pasal 844 Burgerlijk Wetboek;

3. Penggantian dalam garis menyimpang diperbolehkan juga bagi para keponakan, ialah dalam hal bilamana di samping keponakan yang bertalian keluarga sedarah terdekat dengan si meninggal, masih ada anak-anak dan keturunan saudara laki-laki atau perempuan darinya saudara-saudara mana telah meninggal lebih dahulu, sebagaimana diatur dalam Pasal 845 Burgerlijk Wetboek.

Ahli waris yang mewaris berdasarkan penggantian memiliki beberapa syarat yang harus dipenuhi dalam kedudukannya sebagai pengganti dalam pewarisan, yaitu:

1. Ditinjau dari orang yang digantikan.

Dasar hukum Pasal 847 Burgerlijk Wetboek yang berbunyi “Tiada seorangpun diperbolehkan bertindak untuk orang yang masih hidup selaku penggantinya".

2. Ditinjau dari orang yang menggantikan:

a. Keturunan sah dari yang digantikan, termasuk keturunan sah dari anak luar kawin. Hal ini menjelaskan bahwa keturunan dari pewaris harus keturunan yang sah, karena yang dipentingkan adalah hubungan hukum antara ahli waris dengan pewaris.

b. Memenuhi syarat untuk mewaris pada umumnya yaitu hidup pada saat warisan terbuka (Pasal 836 Burgerlijk Wetboek, dengan pengecualian Pasal 2 ayat 2 Kitab Undang Undang Hukum Perdata tentang bayi dalam kandungan), bukan orang yang dinyatakan tidak patut mewaris, serta tidak ditiadakan hak mewarisnya oleh pewaris dengan surat wasiat.

Penghibahan yang terdapat dalam buku III pasal 1666-1693 BW, pada pasal 1666 BW memuat pengertian dari hibah adalah suatu perjanjian dimana pemberi hibah memberikan sesuatu barang kepada penerima hibah yang diberikan secara cuma- 
cuma dan tidak dapat ditarik kembali kecuali terjadinya keadaan tertentu, hibah harus disertai dengan bukti, seperti adanya akta otentik yang dibuat oleh notaris dan harus disimpan oleh notaris yang mengurusi mengenai akta tersebut, jika hal tersebut tidak dipenuhi maka akan batal demi hukum. Adapun yang tidak perlu dengan akta otentik yaitu penghibahan terhadap benda surat piutang dan benda bergerak hal tersebut melalui penyerahan nyata. ${ }^{3}$ Penghibahan tidak boleh dilakukan oleh sembarang orang dalam pasal 1677 BW anak-anak di bawah umur tidak boleh memberikan hibah kepada orang lain kecuali yang telah ditentukan oleh undang-undang ini. pengecualian dalam pasal 1688 BW yaitu jika syarat penerima hibah tidak terpenuhi, jika penerima hibah telah melakukan kejahatan terhadap pemberi hibah, apabila penerima hibah menolak untuk memberikan nafkah terhadap pemberi hibah yang jatuh miskin. Menurut pasal 1667 BW penghibahan kepada orang lain benda nya harus ada, jika bendanya belum ada dan baru dijanjikan di hari kemudian maka hibah dinyatakan batal. Terdapat dalam Burgerlijk weatboek mengenai penarikan hibah dengan perumpamaan secara diam-diam yaitu :

1. Ada kemungkinan pembuat wasiat membuat wasiat secara berturut-turut satu dan lainnya berbeda misalkan pembuat wasiat ingin memberikan hak tanahnya kepada $X$ di wasiat lain pembuat wasiat ingin memberikan hak tanah tersebut kepada $Y$;

2. Pada pasal 966 BW menjelaskan bahwa barang yang di hibah wasiatkan bukan milik pewaris entah pewaris tahu atau tidak maka hibah wasiat tersebut akan batal;

3. Pada pasal 934 BW menjelaskan bahwa pembuat wasiat dapat meminta wasiat olografisnya sewaktu-waktu untuk dicabut kembali dengan pertanggungjawaban jika maka wasiat tersebut dinyatakan dicabut kembali. ${ }^{4}$ Jadi hibah wasiat yang dimaksudkan di sini ialah wasiat yang berisi hibah

3 Utami \& Dewi Sartika, 'Akibat Hukum Pemberian Hibah Yang Melebihi Batas Legitieme Portie' (2016) 4 Jurnal IUS Kajian Hukum dan Keadilan.

4 Husni Muhamad, 'Kedudukan Hibah Wasiat Menurut Hukum Islam Dan Hukum Perdata' (2019) 15 Al Maslahah. 
yang pelaksanaannya terjadi setelah di pewaris meninggal dunia bukan hibah yang dimaksud dalam Buku Ketiga Kitab Undang-Undang Hukum Perdata yang tidak menyinggung tentang hibah wasiat meskipun pada dasarnya hibah wasiat memiliki unsur adanya pemberian. Hibah wasiat menurut Pitlo, adalah apa yang didapat oleh penerima hibah wasiat itu. Sedangkan penerima hibah wasiat (legataris) ialah seseorang tertentu yang berdasarkan ketetapan pewaris dalam suatu wasiat menerima barang tertentu (zaak/Zaken) atau sejumlah benda yang dapat diganti (vervangbare zaken). Legataris termasuk kategori penerima hak dengan atau secara hak khusus.

Mengenai ketentuan hibah yang diberikan kepada orang lain di dalam hukum perdata memang tidak diatur tetapi dalam undang-undang harus memperhatikan bagian tentang hak mutlak. Berdasarkan latar belakang di atas, maka ditentukan dua rumusan masalah yang akan dibahas yaitu ketentuan hukum terkait hibah wasiat dan akibat hibah wasiat yang melanggar legitime portie.

\section{Ketentuan Hukum Terkait Hibah Wasiat}

Menurut hukum wasiat (testament) adalah kehendak dari pembuat saat masih hidup dan wasiat akan berlaku jika pembuat telah meninggal, wasiat juga dapat ditarik kembali oleh pembuatnya. ${ }^{5}$ Burgerlijk Wetboek mengatur hibah wasiat dalam Buku Kedua tentang Kebendaan dalam Bab XIII tentang surat wasiat pada Bagian VI tentang Hibah Wasiat, berbeda dengan hibah yang diatur dalam Buku Ketiga tentang perikatan karena hibah wasiat memiliki unsur yang lebih mendekati dengan wasiat dibanding dengan sebuah perjanjian bernama yang diatur dalam Buku Ketiga karena jelas bahwa hibah wasiat merupakan salah satu jenis dari wasiat apabila dilihat dari isinya dan pelaksanaanya berbeda dengan hibah yang mana hibah wasiat dilaksanakan setelah seseorang meninggal dunia. Hibah Wasiat diatur dalam Pasal 957-972 Burgerlijk Wetboek dan juga disinggung dalam Pasal 902 Burgerlijk Wetboek. Terdapat tiga macam cara membuat hibah

5 Oemarsalim, Dasar-Dasar Hukum Waris Di Indonesia (Rineka Cipta 1991).[82]. 
wasiat yang terdapat dalam pasal 931 BW, yaitu:

1. Testament rahasia (geheim) terdapat dalam pasal 940 dan 941 BW bahwa testament ini penulis menulis sendiri isi wasiat tersebut dan dimasukkan ke amplop tersegel llau diberikan kepada notaris untuk disimpan;

2. Testament tak rahasia (openbaar) terdapat dalam pasal $938 \mathrm{BW}$ bahwa wasiat dibuat dihadapan notaris dan mengajukan dua orang saksi;

3. Testament tertulis sendiri (olografis) testamen ini biasanya bersifat rahasia atau dapat juga tidak rahasia, testament ini dibuat oleh notaris dan ditandatangai oleh yang meninggalkan harta serta surat tersebut disimpan oleh notaris. ${ }^{6}$

Pewaris memiliki hak atas harta yang telah ditinggalkan, biasanya pewaris membuat wasiat yang berisi kehendaknya dan telah diatur dalam Burgerlijk Weatboek yang berisi :

1. Pasal 954 BW menjelaskan bahwa terdapat pengangkatan waris (erfstelling) dimana orang yang mewasiatkan kepada satu orang atau lebih untuk diberikan harta peninggalannya seteah pewasiat meninggal.

2. Legaat ialah pemberian hak dengan dasar surat wasiat, orang yang menerima legaat disebut dengan legataris.

Kehendak di dalam wasiat tersebut tidak semuanya dapat dilaksanakan karena termuat dalam pasal $872 \mathrm{BW}$ wasiat tidak boleh bertentangan dengan undang-undang, dalam wasiat juga terdapat seseorang sebagai ahli waris namun bukan menurut undang-undang. Terdapat aturan mengenai wasiat sebagai berikut:

1. Pasal $874 \mathrm{BW}$ mengatur mengenai harta peninggalan adalah kepunyaan ahli waris menurut undang-undang. Pasal 875 BW mengatur tentang pengertian dari wasiat, pasal $876 \mathrm{BW}$ mengatur tentang pemberian wasiat diberikan melalui hak umum dan hak khusus, pasal 877 BW mengatur tentang surat wasiat untuk keuntungan keluarga atau orang dan ahli waris yang memiliki hubungan darah dengan pembuat wasiat menurut undang-undang, pasal 878 BW mengatur tentang wasiat untuk kepentingan orang yang membutuhkan tanpa memandang agama;

\footnotetext{
6 Muliana \& Akmad Khisni, 'Akibat Hukum Akta Hibah Yang Melanggar Ha Mutlak Ahli Waris (Legitieme Portie)' (2017) 4 Jurnal Akta.
} 
2. Orang yang cakap untuk membuat wasiat adalah orang yang dapat berfikir secara jernih dan berakal sehat, anak dibawah delapan belas tahun tidak diperbolehkan untuk membuat surat wasiat. Dalam perkawinan barang dari suami dan istri dapat menghibah wasiatnya diambil dari harta bersama tersebut dan sekedar bahwa itu barang mereka masing-masing. Seorang anak juga tidak dapat menghibah wasiatnya umtuk kepentingan walinya dan anak yang sudah berumur delapan belas tahun tidak dapat menghibah wasiatkan bekas walinya, kecuali wali tersebut telah menutup perhitungan waliannya; ${ }^{7}$

3. Pasal 944 ayat (2) BW menjelaskan dalam membuat wasiat terbuka para saksi tidak boleh ahli waris, keluarga(yang masih memiliki hubungan darah), menantu, penerima hibah, pembantu notaris;

4. Hak mutlak yang diberikan kepada ahli waris menurut undang-undang dalam garis lurus kebawah maupun keatas, hal mutlak (legitime portie) diatur dalam pasal 913 BW. sekalipun ada wasiat legitime portie harus lebih diutamakan dan tidak boleh dirugikan akibat adanya wasiat tersebut.

Akta otentik dalam penulisan surat wasiat memiliki akibat hukum termuat dalam pasal 1870 BW bahwa akta otentik diantara pihak-pihak dan ahli warisnya atau mereka yang mendapat hak itu adalah bukti sempurna tentang isi yang ada di dalamnya, sehingga pada pasal tersebut bahwa surat wasiat harus disahkan serta didaftarkan ke pihak yang memiliki kewenangan, apabila tidak didaftarkan maka akan memiliki akibat hukum sama dan berlaku juga bagi surat wasiat tersebut. ${ }^{8}$ Menurut pendapat J.Satrio bahwa jika terdapat wasiat sah maka surat wasiatnya harus dilaksanakan oleh seluruh ahli waris. ${ }^{9}$ Yang bertujuan agar kehendak yang pembuat surat wasiat dapat dilaksanakan.

Mengenai hal pembatalan terhadap akta hibah wasiat yang telah dibuat dengan melihat syarat-syarat yang bisa dipenuhi dalam hibah tersebut, apakah terdapat akta hibah jika tidak ada akta maka ahli waris dapat mengajukan gugatan ke pengadilan untuk membatalkan hibah tersebut, termuat dalam pasal 1682 BW bahwa tidak ada hibah kecuali yang ada pada pasal 1687 BW yang menjelaskan bahwa hadiah yang diberikan secara langsung berupa barang

7 M.Wijaya, 'Tinjauan Hukum Surat Wasiat Menurut Hukum Perdata' (2014) 2 Jurnal Ilmu Hukum Legal Opinion.

8 Habibulloh, 'Analisis Pembagian Harta Warisan Berdasarkan Wasiat Yang Tertuang Dalam Akta Notaris (Menurut Hukum Perdata Dan Hukum Islam)' (2018) 12 Jurnal Penelitian dan Kajian Ilmiah Menara Ilmu.

9 J.Satrio, Hukum Waris (Alumni 1992).[179]. 
bergerak berwujud, surat piutang yang dibayarkan tidak perlu akta notaris. Agar sah akta otentik tersebut harus dibuat oleh pejabat yang berwenang dan adanya objek yang akan dihibahkan. ${ }^{10}$

\section{Akibat Hukum Hibah Wasiat Yang Melanggar Legitime Portie}

Dalam Burgerlijk Wetboek pembatasan mengenai hibah wasiat mengacu pada harta yang akan dibagikan pada ahli waris karena terdapat hak mutlak (legitime portie) yang telah ditentukan oleh undang-undang. Secara hukum jika hibah wasiat melanggar legitieme portie akan mejadi batal demi hukum,tetapi terdapat kaidah yang dibuat oleh Mahkamah Agung bahwa jika ada pelanggaran terhadap legitime portie ahli waris, jika ahli waris tersebut merasa tidak dirugikan maka sifatnya menjadi dapat dibatalkan, jika ahli waris tidak menuntut bagiannya ke pengadilan maka akta tersebut dapat dianggap sah. ${ }^{11}$ Termuat dalam pasal $913 \mathrm{BW}$ yang dimaksud legitime portie adalah bagian dari harta peninggalan pewaris setelah meninggal yang harus diberikan kepada ahli waris, ahli waris yang dimaksud adalah ahli waris keturunan garis lurus menurut undang-undang. Jadi pewaris tidak boleh menetapkan sesuatu pada saat masih hidup maupun melalui wasiatnya atau meberikan hibah pasa siapapun terhadap harta peninggalannya yang dapat merugikan ahli waris yang telah ditetapkan oleh undang-undang. Pasal 914 BW memuat tentang bagian legitime portie keturunan garis lurus ke bawah yaitu:

1. Jika pewaris hanya meninggalkan satu anak sah dalam garis lurus kebawah maka anak tersebut akan mendapat bagian seperdua dari harta yang ditinggalkan pewaris karena kematian;

2. Jika pewaris meninggalkan dua anak sah dalam garis lurus kebawah maka bagian tiap anak adalah duapertiga bagian dari pewaris kerena kematian;

3. Jika pewaris meninggalkan tiga anak atau lebih maka bagiannya tiga perempat bagian.

\footnotetext{
10 Djusfi Apri Rotin \& Winata Jumadi, 'Penyelesaian Sengketa Hibah Menurut Kitab Undang-Undang Hukum Perdata' [1991] Jurnal Ius Civile.

11 Muliana \& Akmad Khisni (n 6).,Op.cit.[742].
} 
Pasal 915 BW memuat bagian legitime portie untuk keturunan garis lurus keatas adalah setengah bagian menurut undang-undang. Pasal 916 BW memuat tentang bagian untuk anak luar kawin yang telah diakui adalah setengah dari bagian yang harusnya diterima anak luar kawin tersebut menurut undang-undang. Jika anak sebagai ahli waris telah meninggal mendahului pewaris maka legitime portie nya akan pindah ke anak yang sebagai penggantinya. Jika legitime portie belum terpenuhi maka akan diambilkan dari wasiat dan tidak memperhitungkan wasiat itu kapan dibuat serta menurut perbandingan wasiat tersebut, jika dari wasiat tidak dapat memenuhi legitime portie maka diambilkan dari hibah yang diberikan kepada penerima hibah dengan memperhatikan tanggal pemberiannya yaitu tanggal dekat kematian dari pewaris dan jika legitieme portie telah dipenuhi maka tidak perlu untuk mengambil dari hibah lain. legitime portie memiliki bagian mutlak sehingga tidak dapat dikurangi bagiannya kecuali ahli waris merasa tidak dirugikan dan ha tersebut telah diatur dalam pasal 924 BW. ${ }^{12}$ sifat dari legitime portie adalah sebagai berikut: ${ }^{13}$

a. Legitimaris dapat menuntut pembatalan dari perbuatan-perbuatan si pewaris yang merugikan legitime portie (bagian mutlak).

b. Si pewaris bagaimanapun tidak boleh beschikken (membuat ketetapan) mengenai bagian mutlak itu.

Berdasarkan Pasal 921 BW, besarnya bagian mutlak atau legitime portie dihitung dengan cara yaitu sebagai berikut: ${ }^{14}$

1. Menghitung semua hibah yang telah diberikan oleh pewaris semasa hidupnya, termasuk hibah yang diberikan kepada salah seorang atau para ahli waris mutlak atau legitimaris;

2. Jumlah tersebut ditambahkan dengan aktiva warisan yang ada;

3. Kemudian, dikurangi utang-utang pewaris;

4. Dari hasil penjumlahan dan pengurangan di atas, kemudian dihitung besarnya bagian mutlak atau legitime portie dari ahli waris mutlak atau legitimaris yang

12 Wiliam Marthianus Setiawan, 'Kedudukan Legitieme Portie Dalam Hal Pemberian Hibah Wasiat Berdasarkan Hukum Waris Burgerlijk Weatboek' (2019) 2 Notaire.

13 Andreas P Senoadji, ‘Penerapan Legitime Portie (Bagian Mutlak) Dalam Pembagian Waris Menurut Kitab Undang Hukum Perdata. (Studi Kasus Putusan Mahkamah Agung Nomor Reg 148/ PK/Perd/1982)' (Universitas Diponegoro 2007).

14 Maman Suparman, Hukum Waris Perdata (Sinar Grafika 2015).[94]. 
menuntut bagiannya.

Besarnya bagian mutlak atau legitime portie yang didapat tersebut adalah jumlah yang benar-benar diterima ahli waris mutlak atau legitimaris yang bersangkutan.

Dalam hal pelanggaran hibah wasiat terhadap legitime portie atau bagian mutlak maka akan menimbulkan akibat hukum tetapi tergantung dari penyikapan legitimaris yaitu jika legitimaris dapat menerima kenyataan begitu saja tanpa menuntut ke pengadilan atau mengajukan gugatan ke pengadilan atas dasar bagian mutlaknya. ${ }^{15}$ Terdapat pertimbangan hakim dalam putusan Nomor 188/ Pdt.G/2013/PN.Smg tentang penghibahan wasiat yang melanggar bagian mutlak (legitieme portie) yaitu akta hibah wasiat tersebut dibatalkan dan membagi harta peninggalan pewaris kepada ahli waris yang ditetapkan undang-undang sama rata, tetapi mengacu pada pasal 920 BW bahwa yang diputuskan hakim kurang tepat karena di dalam Burgerlijk Weatboek terdapat solusi yaitu pemotongan hibah wasiat atau inkorting jika melanggar bagian mutlak bagi ahli waris. supaya sesuai dengan aturan pada pasal 920 BW maka seharusnya hakim dapat melakukan pertimbangan dengan pasal tersebut. ${ }^{16}$ Bahwa juga undang-undang tidak memilih penyelesaian yang ketiga, sebagaimana pada Pasal 924, 925, 926, 927 dan 928 Kitab Undang-Undang Hukum Perdata tidak diperbolehkannya ada ganti rugi saat ada penuntutan dari ahli waris yang berhak atas bagian mutlak. Jadi ternyata undangundang memilih penyelesaian yang kedua, yaitu "eenvoudige vernietigbaarheid" (dapat dibatalkan secara sederhana).

\section{Kesimpulan}

Burgerlijk Weatboek hak bagi ahli waris legitimaris yang berkenaan dengan adanya bagian mutlak yang dilanggar untuk mendapatkan bagian mutlaknya

\footnotetext{
15 M.U.Sembiring, Beberapa Bab Penting Dalam Hukum Waris Menurut Kitab Undang-Undang Hukum Perdata (Fakultas Hukum Universitas Sumaetra Utara 1989).[81].

16 Rivera Wijaya, 'Akibat Hukum Terhadap Penghibahan Seluruh Harta Warisan Oleh Pewaris Sehingga Melanggar Legitieme Portie Ahli Waris Ditinjau Dari KUHPerdata (Study Putusan Nomor 188/Pdt.g/2013/PN.Smg)' (Media Neliti).
} 
dalam pembuatan surat wasiat (testament), yaitu dengan memberikan hak untuk mengajukan tuntutan terhadap wasiat yang secara jelas telah melanggar hak mutlak mereka. Hak yang diberikan oleh undang-undang adalah hak untuk mengajukan tuntutan pengurangan atau pengembalian terhadap wasiat yang diberikan kepada pihak ketiga yang di dalam wasiat tersebut terhadap harta yang menjadi bagian mutlak (legitime portie). Para ahli waris legitimaris berhak mengajukan tuntutan untuk memenuhi legitime portie mereka melalui inkorting pengurangan pemotongan dari wasiat, dengan cara perbandingan diantara ahli waris yang diberikan melalui surat wasiat. Setelah didapat hasil perbandingannya maka dihitunglah bagian mutlak ahli waris legitimaris dengan cara, bagian yang diberikan dalam surat wasiat dikurangi hasil perbandingan dikalikan dengan keseluruhan kekurangan bagian mutlak. Adapun urutan untuk melakukan inkorting/pengurangan dalam suatu wasiat adalah, pertama dari ahli waris yang non legitimaris (garis kesamping, janda/duda, saudara- saudara), kedua dari wasiat (hibah wasiat dan erfstelling), dan ketiga di inkorting dari hibah yang diberikan oleh pewaris semasa ia hidup. Jika setelah di inkorting dari non legitimaris, bagian mutlak belum terpenuhi, maka dilanjutkan dengan inkorting terhadap ahli waris dalam wasiat, jika belum terpenuhi juga bagian mutlak, maka di inkorting dari hibah-hibah (Pasal 916a BW). Sedemikian pentingnya hak mutlak para ahli waris legitimaris sehingga BW, memberikan perlindungan dengan membatasi kebebasan pewaris dalam membuat wasiat dan memberikan hak untuk mengajukan tuntutan untuk melakukan pengurangan jika wasiat secara nyata dan benar-benar melanggar legitime portie, dengan tujuan agar ahli waris legitimaris "harus" mendapatkan apa yang menjadi hak mutlak mereka terhadap harta peninggalan pewaris.

\section{Daftar Pustaka}

\section{Buku}

J.Satrio, Hukum Waris (Alumni 1992).

M Idris Ramulyo, Perbandingan Hukum Kewarisan Islam Dengan Kewarisan Menurut 
Burgerlijk Wetboek (BW) (Sinar Grafika 2000).

Maman Suparman, Hukum Waris Perdata (Sinar Grafika 2015).

Oemarsalim, Dasar-Dasar Hukum Waris Di Indonesia (Rineka Cipta 1991).

Prodjodikoro W, Hukum Warisan Di Indonesia (Is Gravennage Vorkink Van Hove) (1962).

\section{Tesis}

Andreas P Senoadji, 'Penerapan Legitime Portie (Bagian Mutlak) Dalam Pembagian Waris Menurut Kitab Undang Hukum Perdata. (Studi Kasus Putusan Mahkamah Agung Nomor Reg 148/PK/Perd/1982)' (Universitas Diponegoro 2007).

M.U.Sembiring, Beberapa Bab Penting Dalam Hukum Waris Menurut Kitab UndangUndang Hukum Perdata (Fakultas Hukum Universitas Sumaetra Utara 1989).

Jurnal

Djusfi Apri Rotin \& Winata Jumadi, 'Penyelesaian Sengketa Hibah Menurut Kitab Undang-Undang Hukum Perdata' [1991] Jurnal Ius Civile.

Habibulloh, 'Analisis Pembagian Harta Warisan Berdasarkan Wasiat Yang Tertuang Dalam Akta Notaris (Menurut Hukum Perdata Dan Hukum Islam)' (2018) 12 Jurnal Penelitian dan Kajian Ilmiah Menara Ilmu.

Husni Muhamad, 'Kedudukan Hibah Wasiat Menurut Hukum Islam Dan Hukum Perdata’ (2019) 15 Al Maslahah.

M.Wijaya, 'Tinjauan Hukum Surat Wasiat Menurut Hukum Perdata' (2014) 2 Jurnal Ilmu Hukum Legal Opinion.

Muliana \& Akmad Khisni, 'Akibat Hukum Akta Hibah Yang Melanggar Hak Mutlak Ahli Waris (Legitieme Portie)' (2017) 4 Jurnal Akta.

Utami \& Dewi Sartika, 'Akibat Hukum Pemberian Hibah Yang Melebihi Batas Legitieme Portie' (2016) 4 Jurnal IUS Kajian Hukum dan Keadilan.

Wiliam Marthianus Setiawan, 'Kedudukan Legitieme Portie Dalam Hal Pemberian Hibah Wasiat Berdasarkan Hukum Waris Burgerlijk Weatboek' (2019) 2 Notaire. 


\section{Laman}

Rivera Wijaya, 'Akibat Hukum Terhadap Penghibahan Seluruh Harta Warisan Oleh Pewaris Sehingga Melanggar Legitieme Portie Ahli Waris Ditinjau Dari KUHPerdata (Study Putusan Nomor 188/Pdt.g/2013/PN.Smg)' (Media Neliti).

How to cite: Yanuar Suryadini dan Alifiana Tanasya Widiyanti, 'Akibat Hukum Hibah Wasiat yang Melebihi Legitime Portie' (2020) Vol. 3 No. 2 Media Iuris. 